The Rule of Five 



\section{The Rule of Five}

Making Climate History

at the Supreme Court

Richard J. Lazarus

The Belknap Press of Harvard University Press

Cambridge, Massachusetts

London, England

2020 
Copyright (C) 2020 by Richard J. Lazarus

All rights reserved

Printed in the United States of America

First printing

Jacket photos courtesy of Getty Images

9780674245150 (EPUB)

9780674245167 (MOBI)

9780674245174 (PDF)

The Library of Congress has cataloged the printed edition as follows:

Names: Lazarus, Richard J., author.

Title: The rule of five : making climate history at the Supreme Court / Richard J. Lazarus.

Description: Cambridge, Massachusetts : The Belknap Press of Harvard University Press, 2020. I Includes index.

Identifiers: LCCN 2019041826 | ISBN 9780674238121 (cloth)

Subjects: LCSH: United States. Supreme Court—Decision making. I

Environmental law-United States-Interpretation and construction.

Classification: LCC KF8748 .L34 2020 I DDC 344.7304/633—dc23

LC record available at https://lccn.loc.gov/2019041826 
To Jeannie, Sam, Jesse, and

Justice John Paul Stevens,

the author of Massachusetts $v$. EPA 
